\title{
Artelogie
}

Recherche sur les arts, le patrimoine et la littérature de l'Amérique latine

1 | 2011

Brésil, questions sur le modernisme

\section{Raizes da arte moderna na Bahia/Brasil}

\section{Maria Helena Ochi Flexor}

URL: https://journals.openedition.org/artelogie/8767

DOI: $10.4000 /$ artelogie.8767

ISSN: 2115-6395

\section{Editora}

Association ESCAL

\section{Refêrencia eletrónica}

Maria Helena Ochi Flexor, «Raizes da arte moderna na Bahia/Brasil», Artelogie [Online], 1 | 2011, posto online no dia 01 março 2011, consultado o 07 janeiro 2022. URL: http://journals.openedition.org/ artelogie/8767 ; DOI: https://doi.org/10.4000/artelogie.8767

Este documento foi criado de forma automática no dia 7 janeiro 2022.

Association ESCAL 


\title{
Raizes da arte moderna na Bahia/ Brasil
}

\author{
Maria Helena Ochi Flexor
}

1 Até o século XIX, a Igreja foi a grande cliente dos artistas baianos. Os pintores, além dos quadros, painéis, tetos, pintavam estandartes, andores e charolas e elaboravam as imagens de vestir e as de roca ${ }^{1}$ para as procissões. Cabia a eles, também, a encarnação e pintura das imagens, sua restauração, pinturas internas de oratórios, caixas, arcas, armários, douramentos. Os escultores, da mesma forma, exerciam funções outras, além de executar as chamadas obras primas, incluindo restauração e modernização de imagens ou repintura restaurativa de quadros.

2 A pintura desses artistas continuou a reproduzir os modelos da segunda metade do século XVIII, tanto nos tetos, quanto nos painéis, através da perspectiva com um, dois ou mais pontos de fuga. Os temas das pinturas e das esculturas, por terem como cliente a Igreja, eram bíblicos ou da tradição da vida dos santos da Igreja Católica e Apostólica Romana reformada, reproduzindo composições européias ${ }^{2}$. A teatralidade das cenas era amenizada sem, no entanto, deixar de ter a profundidade ditada pelo claro-escuro. A forma, a técnica e a policromia eram as mesmas dos setecentos, não faltando as molduras barroco rococós como complemento decorativo.

3 Ainda nos meados desse século XIX, a pintura e a escultura eram feitas nos moldes das corporações medievais. Embora, desde os setecentos, os artistas não dependessem mais do controle administrativo das Câmaras, como acontecera com os ofícios mecânicos, os ateliês tinham a mesma estrutura e funcionamento das tendas ou oficinas dos artesãos. Estampas e obras de grandes mestres serviam de modelos como era a prática, visto que a maestria só era alcançada quando se copiava, o mais perfeitamente possível, esses modelos. A aprendizagem fazia-se nos ateliês ou oficinas dos mestres e na prática.

4 O desenho foi a primeira forma de ensino artístico fora desses ateliês. As chamadas aulas públicas de desenho iniciaram-se em 1813, tendo como professor e diretor Antônio da Silva Lopes, português que, segundo Manoel Querino ${ }^{3}$, era deficiente como professor, devido à morosidade do método que adotava. Afirmava esse autor que o desenho duma cabeça, de tamanho natural, poderia ocupar um aluno durante seis 
meses. Mesmo assim, alguns desenhistas concluíram esse curso e, entre eles, Fortunato Cândido da Costa Dormundo, que "como copista, imitava com a pena qualquer gravura". Vê-se que a prática da cópia do século XVIII continuava.

5 Esse professor ministrou aulas até 1820 e, no ano seguinte, foi nomeado, como lente substituto da cadeira, o artista Antônio Joaquim Franco Velasco, considerado bom professor. Sua atuação prolongou-se até 1833, época em que o curso passou para a orientação de José Rodrigues Nunes. Este permaneceu até 1860 e, posteriormente, foi substituído por seu filho, Francisco Rodrigues Nunes ${ }^{5}$. Franco Velasco também foi responsável pela cadeira de desenho criada em 1828, no Convento de São Francisco. Embora ministrada no Convento, tinha caráter público. Isto explica a sua maior habilidade para os retratos e para temas que se distanciavam dos bíblicos, mostrando já ter sido atingido pela renovação promovida pela Missão Artística Francesa do Rio de Janeiro ${ }^{6}$.

6 Fora de instituições, em 1841, Paul Geslin, pintor de história da Academia de Paris anunciava, em Salvador, lições de pintura e desenho com a utilização de um método fácil para os principiantes, segundo informações de Manoel Querino. 0 mesmo autor deu notícias de que no ano de 1845 existia, na Praça de Palácio, um estabelecimento de Belas Artes, pertencente a Luís Antônio Dias, onde se ensinava [...] "um sistema completo de ceroplastia, ou seja, imitar ao natural, com a máxima semelhança, qualquer objeto; desenho e pintura oriental e mais de doze ramos diferentes". Se for correta a informação de Querino, a Bahia já tinha conhecimento do que se passava em Paris, pois se falava em imitar o natural, bem como o desenho e as pinturas orientais.

7 Uma década depois, no dia 18 de maio de 1856, o Dr. Antônio José Alves reunia, no edifício onde funcionaria a Academia de Belas Artes, então residência do Conselheiro Jonathas Abbott, um grupo de homens de letras. Estes fundaram a Sociedade de Belas Artes com o "objectivo de despertar o gosto pelas manifestações literárias, elevando moralmente a classe dos artistas e, ainda, dando a oportunidade, oferecendo exposições anuais. Mais tarde, a Sociedade de Belas Artes convidou as pessoas que quisessem vender quadros, esboços, desenhos, gravuras ou outras quaisquer peças de arte, para organização da sua biblioteca", bem como promoveu concursos de pintura histórica, principalmente em homenagem ao 2 de Julho'.

8 A Assembléia Provincial, pelo que consta, chegou a votar crédito para a construção de um Palácio de Belas Artes que não se concretizou e, entre 1841 e 1870, a Província da Bahia já enviava alguns artistas para se aperfeiçoar na Europa, independentemente de instituições oficiais ou particulares. Foram estudar em Paris Francisco Rodrigues Nunes, que pertencia à Sociedade de Belas Artes e ensinava desenho nas aulas públicas, para estudar pintura; Francisco Moniz Barreto Filho, para estudar música e pintura e Francisco de Azevedo Monteiro Caminhoá para estudar arquitetura civil, entre outros ${ }^{10}$. A França e a Itália eram os países preferidos.

9 Já em 1864, o Dr. Antônio Álvares da Silva tinha apresentado projeto de lei para fundar um Liceu de Artes e Ofícios. Só em 1871, artistas e operários, julgando estreitos os moldes do Montepio dos Artífices e do Montepio dos Artistas, desejando ampliar seus horizontes, prepararam os meios para a fundação de um estabelecimento de ensino profissional, teórico e prático que, ao mesmo tempo, fosse uma instituição de beneficência ${ }^{11}$. A visita de D. Pedro II à Bahia, alguns anos antes, foi fundamental para a fundação do Liceu de Artes e Ofícios que se efetivou em 1872. 
10 No mesmo ano de 1871, o Diretor Geral da Instrução Pública, em Relatório, dava conta da existência das cadeiras de música e desenho no Liceu Provincial ${ }^{12}$ sem fazer parte do curso, salientando que "seria fácil a criação de um modesto Instituto de Belas Artes, aumentando-se uma cadeira de Escultura", concluindo, no entanto que, se essa idéia não fosse aprovada, as duas cadeiras deveriam passar para a Escola Normal. O Liceu Provincial possuía também uma galeria de pintura, - a galeria Jonathas Abbott - que, segundo o mesmo diretor, "não tem sido visitada, como deveria ser, pois é importante, $e$ contém quadros preciosos" ${ }^{13}$. Em relação à Escola Normal dizia-se que o ensino de desenho de imitação, além de prestar serviços outros, forma o gosto e desenvolve o sentimento do belo ${ }^{14}$.

11 Como a Escola Normal, todas as instituições de ensino, na segunda metade do século XIX, tinham um museu de história natural, um industrial e um de artes e oferecia aulas de dança, música e desenho para os meninos e para meninas. Estas tinham, ainda, aulas de prendas domésticas.

Nos meados de 1877, se tem notícias de um Instituto Artístico, sob a direção do Dr. Barbosa Nunes, cujas aulas podiam ser freqüentadas pelos associados e seus filhos ${ }^{15}$. Não se encontrou muitas informações sobre esse Instituto.

Esse foi um período em que a classe média começava a atingir o poder e foi quando o bacharel em direito principiou a ceder lugar a outros profissionais liberais nesse mesmo poder. Estes, voltados para as modernidades, novas pesquisas e tecnologias, inovaram, também, o ambiente social, criando instituições beneficentes, abolicionistas e culturais. Como políticos, transitavam nas altas esferas soteropolitanas, bem como nas da Corte do Rio de Janeiro. Foram eles, sobretudo, os idealizadores e portadores das inovações introduzidas na Bahia nessa segunda metade do século XIX.

Dentre essas instituições, inspirada na Academia Imperial de Belas Artes do Rio de Janeiro, fundou-se a Academia de Belas Artes da Bahia em 17 de dezembro de 1877. Foi criada por Miguel Navarro y Cañizares, pintor espanhol, João Francisco Lopes Rodrigues, pintor, João Francisco Lopes Rodrigues Filho, pintor, José Nivaldo Allioni, engenheiro, Virgílio Clímaco Damásio, médico, Austricliano Ferreira Coelho, professor primário, durante o governo do desembargador Henrique Pereira de Lucena, futuro barão de Lucena ${ }^{16}$.

A partir dessa fundação, foram o Liceu de Artes e Ofícios e Academia de Belas Artes que passaram a ditar os padrões estéticos que vigoraram durante longo período na Bahia, especialmente em Salvador. A República, que transformaria a Academia em Escola de Belas Artes, manteria, por muitos anos ainda, os mesmos padrões estéticos ${ }^{17}$.

16 A Bahia, desde o primeiro governo de J. J. Seabra (1912-1916), no entanto, se engajara na ideologia do progresso, da normatização da sociedade, do higienismo e a cidade começava a se transformar com as reformas urbanas e arquitetônicas, tendentes à monumentalização. Salvador deveria ter, então, em torno de 250.000 habitantes, pois o censo de 1900 dera 205.813 e o de 1920 apontou $283.422^{18}$. A Bahia dava seus primeiros passos no mundo moderno. E J.J. Seabra teve um outro período de governo, de 1920 a 1924, quando continuou suas propostas de modernização, ou melhor, haussmannização da cidade $^{19}$.

17 É precisamente o percurso dos primeiros passos da arte moderna na Bahia que se pretende tratar, buscando sua inserção no tempo e no espaço baianos, até o 
aparecimento dos primeiros artistas plásticos renovadores ${ }^{20}$, salientando, quando necessário, seus principais atores.

Fala-se em arte moderna na Bahia dentro de um conceito bastante amplo. Usam-se as expressões arte moderna e modernismo ${ }^{21}$ como contraposição à postura clássico realista. Entenda-se, sobretudo, arte moderna como uma etapa decorrente do movimento de construção de um novo tempo, destruidor de uma cultura artísticoliterária anterior.

19 Alguns estudos já deram pistas sobre o tema. Dentre esses pode-se citar os trabalhos de José Valladares ${ }^{22}$, Ceres Pisani S. Coêlho ${ }^{23}$, Sante Scaldaferri ${ }^{24}$, Roberto Pontual ${ }^{25}$, Selma C. Ludwigi ${ }^{26}$, Juarez Paraíso ${ }^{27}$ e poucos outros.

20 Dão-se apenas algumas trilhas para um estudo mais amplo, que está por se fazer, sobre a arte moderna na Bahia e no Brasil, visto que, todas as publicações, que estampam referências à história da arte brasileira no período mais recente, tratam apenas do Rio de Janeiro e São Paulo ${ }^{28}$. Esse eixo geográfico é tomado como se a Semana de Arte Moderna de 1922, realizada em São Paulo, e seus desdobramentos regionais, definissem os mesmos quadros ou estivesse completamente ausentes, nas demais regiões brasileiras tidas, até o presente, como periféricas nas artes plásticas modernas brasileiras.

21 Se se tomar São Paulo e o Rio de Janeiro como parâmetros, pode-se dizer que a arte moderna chegou tardiamente à Bahia. Nela, o amor ao prestígio popular e literário da retórica, oratória na tribuna e no púlpito alimentava o gosto pelo antigo e embalava a tendência pelo neoclassicismo, realismo e romantismo, tão retóricos quanto o discurso. o modernismo encontrou a Bahia assentada em seu tradicionalismo, com uma economia incipiente e culturalmente dependente. A dependência política, econômica, religiosa, social e cultural de Portugal, por longo período, deixou-lhe como herança o gosto pelo novo europeu.

A população diminuta ${ }^{29}$, a migração de intelectuais para o Sul, a inexistência de instituições oficiais, ou oficiosas, como museus, galerias, salões etc., ainda na década de 1940; a falta de rotas de comunicação interna e rápida com os grandes centros culturais; a falta de desenvolvimento industrial, técnico e científico foram fatores que não permitiram, de um lado, o conhecimento instantâneo do que se passava em matéria de criações artísticas novas em outros meios e, de outro, para que o modernismo não encontrasse campo próprio e mentalidade para a sua instalação.

23 As instituições oficiais, como o Liceu de Artes e Ofícios e a Escola de Belas Artes estavam ainda bastante comprometidos com um passado de formação clássica, herdeira da estadia de D. João VI no Brasil. A europeização, promovida por Manoel Vitorino ${ }^{30}$, nos fins do século XIX, fez entrar sem cessar nessas instituições, reproduções, gessos artísticos e originais vindos especialmente da Itália e de Paris, que serviram, por longa data, como modelos para os alunos e à apreciação da população. Seguia-se, na Bahia, e de resto no Brasil, as idéias vigentes da França onde, depois da Revolução Francesa, o neoclassicismo dirigiu-se à cópia direta dos modelos da Antiguidade clássica e do Renascimento.

Quando acontecia a Semana de 22, em São Paulo, José Allioni escrevia no "Diário Oficial”, Edição Especial, comemorativo ao Centenário da Independência da Bahia, em 1923, dizia: "na [escultura] de pedra, quasi todos os bustos e figuras, assim também, os ornatos, altos e baixos relevos, têm sido feitos no extrangeiro ou no Rio, onde existem bons 
esculptores". Nessa mesma época, o escultor italiano, Pasquale de Chirico, segundo o modelo clássico, terminava o monumento a Rio Branco, hoje junto ao Relógio de São Pedro. Já fizera o monumento ao Conde dos Arcos, no Comércio, e trabalhava no conjunto de Castro Alves, colocado na praça do mesmo nome. Na arquitetura predominava o estilo ogival, resquício das idéias românticas européias, ou românico bizantino, que foram fixadas nas reconstruções da Igreja de São Pedro Velho e Convento das Mercês e, ainda, as neoclássicas, como no Palácio Rio Branco e na fachada Caminhoá da Câmara Municipal, hoje inexistente. É nesse período que se discutia, por outro lado, em nome da modernização, do higienismo e salubridade, a demolição da Igreja da Sé que acabou cedendo lugar a uma praça e aos bondes ${ }^{31}$.

As belas artes, como eram chamadas a pintura, a escultura e a arquitetura, estavam encerradas nos muros da Escola de Belas Artes, admiradas por seus professores e alunos. Ao público pouco, ou quase nada, diziam as belas artes. Os órgãos governamentais, depois das grandes reformas urbanas de J. J. Seabra, ainda estavam embevecidos pelos engenheiros e arquitetos italianos, que cuidaram da monumentalização dos edifícios públicos e de toda a série de ornamentos que foram largamente importados da Itália e França para satisfazer ao gosto classicizante ${ }^{32}$. Além de ornamentar aqueles edifícios, passaram a estar presentes nas inúmeras platibandas, muros e escadarias e dependências de palacetes particulares.

Alimentando esse gosto, existiam as pensões de viagens de estudos, concedidos pelas Escolas de Belas Artes do Rio de Janeiro e, a seu exemplo, a da Bahia, ou pelos próprios governos provincial e imperial. As pensões para viagens de estudos eram instituição da Academia de Belas Artes de Paris e, com as mesmas finalidades, foram criadas nas Escolas de Belas Artes do Brasil. Os artistas agraciados com esse benefício, em geral, estudavam em Paris nas academias ou ateliês neoclássicos ${ }^{33}$. A grande maioria desses artistas permaneceu indiferente às grandes inovações que se procediam, então, na Europa que, até 1922, conhecera as mudanças do impressionismo aos primeiros movimentos abstratos e já preparava o caminho para o surrealismo. E, no entanto, as maiores ousadias dos artistas paulistas revolucionários de 1922 não ultrapassaram o cubismo, misturado com idéias pós-impressionistas, fovistas e futuristas.

A Bahia estava mais atrasada ainda, pois, enquanto isso, professores, ex-alunos e alunos da Escola de Belas Artes "encontravam-se perfeitamente capacitados para caricaturar ou retratar com a máxima semelhança as nobres damas e os ilustres senhores, fixar os grandes feitos históricos, conferindo-lhes as necessárias pompas, ou os temas mitológicos com extraordinário sentimentalismo, melodramático, tão a gosto na época, além de estarem habilitados para a decoração das magníficas salas e salóes cheios de papéis, pinturas e estuques". ${ }^{34}$

Segundo Zélia Maria Póvoas "realmente quase nada se exigia da escola que ela não pudesse oferecer, desde quando o exigido não fugisse aos preceitos acadêmicos" 35 . Manoel Lopes Rodrigues, Alberto Valença e o próprio Presciliano Silva, que fora pensionista do Estado na Europa, absorveram superficialmente o impressionismo, especialmente este último, criando um estilo pessoal que seria seguido por alguns discípulos.

À Escola chegaram as notícias das influências da fotografia na pintura impressionista, mas ali a pintura se transformou em cópias de modelos tirados de fotografia. Desde 1893 o engenheiro e professor José Allioni, que tinha estado em Paris, fazia ver a "grande utilidade de uma máquina fotográfica para a Academia", ficando encarregado da sua compra. Um ano depois, o então diretor, Braz do Amaral, dizia que o motivo da reunião 
de Congregação era para os colegas assistirem a "primeira experiência da máquina fotográfica" ${ }^{\prime \prime}$.

30 Em função desse aparelho, a proposta de reforma do curso de desenho, aprovada em 1894, feita pelo professor Oseas dos Santos, mostrava qual era o emprego da máquina fotográfica na Escola de Belas Artes: "3a parte - Cópia de modelo vivo a fusim. A fotografia entrará no estudo da paisagem ao ar livre, para melhor orientação dos alunos sobre distinção de planos, perspectiva aérea, etc" ${ }^{{ }_{37}}$. Absorveram superficialmente as inovações tecnológicas e seus reflexos sobre a arte. Não podiam, portanto, incorporar o impressionismo totalmente.

31 A maioria dos artistas baianos, de então, estava ligada à Escola de Belas Artes. Entre eles se contavam os que exerceram sua atividade nos quatro primeiros decênios do século XX: Pasquale de Chirico, Ismael de Barros, Augusto Buck, Francisco Vieira Campos, Manoel Mendonça Filho, Robespierre de Farias, Emídio Magalhães, Raimundo Aguiar, Otávio Torres, Agripiniano de Barros, Presciliano Silva, Alberto Valença, e outros.

As mudanças deram-se gradativamente e o ambiente foi, indiscutivelmente, preparado pela literatura. Portanto, fora da academia o meio cultural foi preparado pelo movimento literário que, se não aceitava os excessos do modernismo paulista, estava de acordo com o seu caráter renovador. Em 1928 surgia a revista Samba com pretensões modernistas. Foram publicados quatro números e já se denominava Mensário Moderno de Letras, Artes e Pensamento, dirigida por Gomes Costa e patrocinada por Severino Martinez $^{38}$. A revista Arco e Flexa surgiu no mesmo ano, sob a responsabilidade de Carlos Chiacchio. Seus seguidores chamavam-se modernos e não modernistas. Circulavam, ainda, a revista Meridiano, da Academia dos Rebeldes, e 0 Momento $^{39}$.

Segundo Teixeira Gomes, "significativamente, "O Momento" traduzia um espírito de rebeldia e inconformismo que longe estava sequer de aflorar nas páginas de "Arco e Flexa". Em comentário de natureza editorial, ou artigos assinados, assumiu posição inflexível contra a veneração baiana pelo passado, o culto estático das tradições da história, considerando ser esse o clima responsável pelo atraso local e que precisava ser denunciado e rigorosamente combatido ${ }^{40}$. Essa crítica registrou a principal característica renovadora que estaria presente, tanto na literatura, quanto nas artes visuais.

Nesse clima, surgiram alguns intelectuais que comungavam pensamento semelhante. Já em torno de Chiacchio ${ }^{41}$ gravitavam diversos intelectuais que se reuniam em uma mesa, - na tavola, marca do periódico Arco e Flexa -, do terraço do Cine Guarany, na Praça Castro Alves, para discutir política, música, artes, letras, medicina e folclore. Pessoalmente, Chiacchio não defendia a renovação total e colocava a Bahia como centro da nacionalidade. As discussões sobre o folclore e a busca das próprias raízes acentuavam o espírito nacionalista tão exacerbado no Brasil de então. Ele apregoava um modernismo baseado nas tradições, evolução do próprio passado, como dizia, um tradicionalismo dinâmic ${ }^{42}$, com continuísmo ${ }^{43}$, evolutivo, contra o primitivismo. Neste sentido, no manifesto Arco e Flexa, criticavam as pesquisas influenciadas pelas inovações européias: "[...] tais autores deixam de lado a tradição que é a própria vida do povo". E chamava a atenção para as características comuns com a América luso-espanhola. Opunha, então, a tanga, o arco e a flecha à máscara, ao florete e à luva, isto é, o nacional contra o europeu. $O$ periódico Arco e Flexa, embora voltado para a literatura em seu último número (4 e 5), de 1929, trazia o subtítulo Mensário de Cultura Moderna ${ }^{4}$, 
sobrepondo-se ao parnasianismo e simbolismo ${ }^{45}$. Como uma das metas do modernismo era dar ênfase à tradição local, coincidindo com os resultados do regionalismo, pode-se dizer que, entre uma fase e outra, não houve interrupção.

Moraes descreveu a fase, que seguiu a Semana de 22, como caracterizada por um movimento geral de busca da originalidade nacional, contra o sentimento de frustração do período anterior, embora se encontre entre eles uma grande continuidade. "Esta termina por assegurar [dizia ele] na adesão aos pressupostos epistemológicos de uma Etnografia e um Folclore que buscavam determinar as qualidades do elemento 'primitivo' definindo-as com relação ao elemento "civilizado" "46. E isso já estava implícito na Arco e Flexa.

Chiacchio defendeu suas idéias pela imprensa. Ocupou-se, durante 18 anos a informar, nos seus rodapés semanais no jornal A Tarde,- chamados Homens e Obras -, sobre as publicações e artes. A partir de 1928 faria oito rodapés com o título Modernistas \& Ultramodernistas $^{47}$ e chamava a atenção para Marinetti, mestre do escândalo, em 22 de fevereiro de 1928.

37 A literatura não estava sozinha. Além das discussões na tavola, por esse período apareciam as primeiras produções cinematográficas, com filmes de curta metragem, focalizando paisagens, costumes e festas de Salvador, realizados por Alexandre Robatto Filho, cuja ação se estenderia até os anos $1950^{48}$.

Embora o modernismo encontrasse na literatura sua primeira defensora, contava em seu meio com intelectuais como Hélio Simões, Eugênio Gomes, Godofredo Filho, e o próprio Carlos Chiacchio, que transitavam entre os artistas plásticos. Assim, para os fins da década de 1930, o mesmo Chiacchio, incansável batalhador e professor da Escola de Belas Artes, junto com Mendonça Filho, Presciliano Silva, Hélio Simões, Raimundo Patury, Roberto Correia instituíram o Salão de ALA - Ala das Letras e das Artes -, que teve início em 1937 e se prolongou até 1949. A cerimônia de abertura, em novembro de 1936, e o primeiro Salão foram realizados nas dependências da Escola de Belas Artes e nos salões na Biblioteca Pública. Chiacchio também editou o Jornal de ALA, dedicado à literatura à e às artes. $O$ movimento ALA só terminou porque seu grande animador faleceu em 1947.

39 A Carta de Ala das Letras e das Artes, lida no ato de sua fundação, tinha evidente influência das idéias difundidas na Semana de 22 , - brasilidade, civismo ${ }^{49}$-, e fugia às regras normais de regimentos numa flagrante forma futurista. No item 8 previa a criação de um Salão Oficial de Belas Artes "para exposições anuaes sob a direção imediata da $E B A$, de cujo corpo docente será formado o juri, que superintenda e encoraje as atividades artísticas do Salão"so. Entende-se, portanto, porque os artistas da ALA não trouxeram muitas inovações, porém, já davam os primeiros passos, mostrando uma pequena abertura, prevendo a criação de um Museu Regional em que se misturassem o antigo e o moderno.

40 As Comissões de Arte da ALA mostravam as tendências estilísticas de então, intimamente ligadas a seus responsáveis: escultura Pasquale de Chirico, arquitetura moderna Diógenes Rebouças, pintura modernista José Guimarães, pintura paisagista Alberto Valença, interiorismo Presciliano Silva, impressionismo Mendonça Filho, pintura de gênero Robespierre de Farias, pintura regionalista Emídio Magalhães, pintura de costumes Alfredo Araújo, pintura humorística Raymundo Aguiar, etc. A tônica do período, ligada à brasilidade, ao civismo, e mesmo ao regionalismo, se encontrava em outras comissões, além daquela que mantinha a ligação das artes com a literatura, bem ao gosto do período. Assim, existiam ainda as comissões de história, 
literatura e arte que previam os estudos de história das artes, sob a responsabilidade de Francisco Conceição Menezes; arte luso-afro-indianista com Affonso Ruy; arte popular e a vida dos arredores com Evandro Balthazar; arte erudita e religiosa com o Padre Manoel Barbosa. A vigésima Comissão previa, ainda, educação do gosto artístico, sob a responsabilidade de Artur Xavier da Costa ${ }^{51}$.

Além do jornal e salões, a ALA, como os futuristas, promoveu conferências, recitais de poesias, festivais, estimulou grupos de teatro amador, de cinema e chegou a ter o apoio do Estado.

Nos Salões da ALA já se percebia alguma diferença entre os artistas. Alguns participantes continuavam suas obras clássicas, outros, entretanto, participavam das primeiras iniciativas para introduzir a arte moderna na Bahia, como: Newton Silva, Abrahão Kosminsky, Jair Brandão, Carl Brussel, Diógenes Rebouças, Maria Célia Calmon, Mário Cravo Júnior. Os Salões da ALA eram anuais e, até então, quase porta-voz da academia, pois Chiacchio chamava de "deformações à reação aos valores tradicionais. A ALA admitia somente o saudável impressionismo romântico que é a seiva tradicional dessa arte que podemos chamar de escola baiana de pintura"52. Na realidade, Chiacchio aderiu apenas momentaneamente ao modernismo, mas, de qualquer forma, abrira caminho e preparara o terreno, junto com 0 Momento e a revista Seiva.

Fora dos salões, em 1932, o baiano José Guimarães, natural de Nazaré das Farinhas e exaluno da Escola de Belas Artes, dava os primeiros passos para a modernidade. Era pintor de paredes quando conheceu Presciliano Silva e, sob sua proteção, ingressou na Escola. O jovem artista realizou uma exposição, em 1928, na Associação dos Empregados no Comércio, na rua Chile, que foi bem recebida pelo público entendido. Chiacchio e Anísio Melhor o estimularam a solicitar uma pensão do Estado para estudar na Europa. Já ganhara o prêmio Caminhoá, da EBA, e obteve a pensão, por cinco anos, chegando a ser aceito no Salão ${ }^{53}$, de 1931, freqüentando, na Academia Julian ${ }^{54}$, o curso do professor Albert Laurens, pré-requisito para o ingresso na Academia de Belas Artes de Paris. Teve que abandonar os estudos, devido à depressão econômica mundial do período ${ }^{55}$. Chiacchio dizia que ele voltara da Europa "todo Cèzanne, todo arte moderna" ${ }^{56}$. Houve críticas até por parte de seus antigos mestres e colegas da academia.

Recém-chegado de Paris, no dia 14 de maio de 1932, realizou uma exposição no andar térreo do recém inaugurado edifício do jornal A Tarde. A exposição era composta de quarenta e dois quadros a óleo, entre nus, paisagens e retratos. Apresentava obras de influências pós-impressionistas, em fase de evolução o que motivou elogio de Eugênio Gomes $^{57}$, articulista daquele jornal, que escreveu: "àqueles que vem contribuindo, por vários modos para que nossa terra se mantenha cada vez mais hostil a qualquer empreendimento de renovação artística, seria lícito recomendar que meditassem sobre o caso do pintor José Guimarães" $"$.

45 A obra desse artista, depois dessa fase, teve tratamento de planos e luzes, deixando de lado os detalhes e dando, definitivamente, abertura às manifestações mais modernas. Por outro lado, José Guimarães foi um dos primeiros a abordar temas regionais, como se vê nas xilogravuras das ilustrações da revista Seiva, em 1939, incluindo figuras e símbolos de candomblé.

Dez anos eram passados, depois da Semana de 1922 de São Paulo, e José Guimarães ainda provocava reações negativas. A propaganda futurista de Marinetti atingira a América espanhola, alguns pontos do Brasil, mas não encontrou muito eco na Bahia, a não ser, em raros textos literários e a denominação do microônibus que levou por 
muito tempo o seu nome. Apesar disso, na Comissão de Formas, Aspectos, Paisagens, de ALA, a pintura modernista estava a cargo de José Guimarães, ainda em 1937.

Sendo quase que a única voz a defender a arte de vanguarda no meio ainda adverso, José Guimarães não levaria à frente, seriamente, sua pintura. Mudou-se para o Rio de Janeiro. Morreu naquela cidade, a 19 de outubro de 1969, onde trabalhou como empreiteiro de pintura de parede, decorador, desenhista, pintando eventualmente, e terminou a vida como professor de desenho do Colégio Pedro II ${ }^{59}$.

48 As críticas contrárias à arte moderna em Salvador, na Bahia e em geral, se sucediam: "Presciliano Silva o pintor de tanto claustro e igreja [...] revela a alma de sua terra no seu pincel e não transige com a moda de não saber pintar, que a convenção chama de futurismo, isto é, arte de não saber representar por desenho nem por cores [...]", dizia Afrânio Peixoto ${ }^{60}$. "Cèzanne costumava dizer que todas as formas da natureza poderiam sintetizar-se num cilindro, num cubo e em uma esfera. Podemos observar hoje o mal que essa maneira de pensar causou aos artistas do século XX, abrindo desse modo uma brecha para os charlatões da pintura contemporânea, que só pensavam em deturpar os verdadeiros sentimentos da arte, procurando com teorias avantajadas da mediocridade, vomitar conhecimentos estéticos e intepretações puramente erroneas para se tornarem "araltos' artísticos embora não passem de verdadeiros 'berlenquins da pintura'.) Felizmente, porem, notemos que muitos jovens inteligentemente estão repudiando esta pintura, reconhecendo que a orientação mais acertada é aquela que se baseia nos conhecimentos preciosos e técnicos dos grandes mestres do passado", afirmava o professor, da Escola de Belas Artes, Emídio Magalhães ${ }^{61}$.

Apenas o movimento da ALA continuava, como grupo, a defender as inovações, embora contidas. Com a morte de Chiacchio, em 1947, os Salões de Ala encerraram-se um pouco depois e diminuíram de intensidade os alardes modernistas que só encontrariam apoio em outro jornalista José do Prado Valladares.

De 1930 a 1959, data de sua morte, José Valladares fez do Museu do Estado ${ }^{62}$ o ponto de irradiação das discussões sobre arte. Só em 1938 o Museu desvinculou-se do Arquivo Público, composto da Pinacoteca e Museu do Estado da Bahia, formado com o acervo da já referida coleção Jonathas Abbott. Em 1946 inaugurou-se o Palacete Góes Calmon para onde se mudou o Museu ${ }^{63}$, no bairro de Nazaré. Na gestão de Valladares foi criado um centro de publicações que editou estudos relativos à arte e história da Bahia, dentro das características regionalistas, que tanto influenciaram os pioneiros da arte moderna em Salvador ${ }^{64}$.

51 Segundo Valladares, ainda em 1952, se discutia sobre a estrutura do Museu de Arte da Bahia e perdurava a questão sobre que tipo de museu se deveria montar, dadas as condições econômicas e culturais em que a Bahia se encontrava, pois já havia instituições que cuidavam da aquisição, conservação, classificação e exposição de obras de arte, a delegacia do Patrimônio Histórico e Artístico Nacional, Instituto Geográfico e Histórico da Bahia, o Instituto Feminino, a Escola de Belas Artes e o Museu de Arte Sacra, então em negociação para organização ${ }^{65}$.

52 Apesar da existência dessas instituições, os artistas particularmente não dispunham de espaços próprios para a exibição de sua produção. Para suprir essa deficiência, muitas vezes, a Biblioteca Pública, o saguão do Palácio Rio Branco, do Instituto Histórico, do jornal A Tarde, na Praça Castro Alves, o Belvedere da Sé, a Associação dos Empregados no Comércio e no hall do Palace Hotel, na Rua Chile, e do Hotel da Bahia, do Cine Guarany, do Edifício Oceania, na Barra, do Edifício Sulacap, do Edifício Sul América, da Associação Cultural Brasil-Estados Unidos - ACBEU -, as vitrinas da Rua Chile serviram 
como locais de mostra. Sem muitas casas de espetáculos, também, contavam com poucos cinemas.

Seria necessário que a Bahia passasse por um processo de transformação para mudar esse quadro. E essa renovação na Bahia foi decorrente, também, daquele processo de fermentação política que conduziu o Sul à Revolução de 1930, que tinha como propósito, como na arte, renovar a República deteriorada. Na Bahia, essa década mostrou, justamente, alguns indícios que levariam ao crescimento da cidade do Salvador, em especial de seu centro comercial, dando início à uma fase de desenvolvimento que a transformaria, finalmente, em Metrópole.

No fim da década, a cidade do Salvador tinha cerca de 290 mil habitantes. Rio Vermelho, Amaralina, Plataforma e Lobato tinham população rarefeita. No Cabula e Pernambués existiam chácaras ${ }^{66}$. Logo, no entanto, como reflexo do aumento da cultura cacaueira, que se iniciara por 1939, a cidade mudaria. Alguns anos, ainda, seriam transcorridos antes que transformações mais profundas tivessem lugar.

Durante o governo de Getúlio Vargas, (1937-1945) houve medidas restritivas que afetaram de alguma forma a cultura, embora reforçasse o patriotismo e nacionalismo. Houve censura com as conseqüentes perseguições a intelectuais e jornais. Contraditoriamente o Estado Novo cuidou de outros aspectos da cultura. Criou-se, por exemplo, o SPHAN - Serviço do Patrimônio Histórico e Artístico Nacional -, em 1938, que começou a defender o patrimônio artístico nacional, instalando uma delegacia na Bahia. Deu apoio aos artistas cariocas. Lúcio Costa, a frente da Escola Nacional de Belas Artes, abriu as portas à modernidade. Nacionalmente, terminava a era dos "clubes" de arte moderna e surgia o Sindicato de Artistas Plásticos. A arte só tomaria impulso após a Guerra quando a fermentação estética recomeçaria com a mola propulsora dos museus $^{67}$.

56 A redemocratização do Brasil abriu o campo para discussões de toda ordem, especialmente as políticas. A partir de 1944-1945 o ambiente, no qual se misturavam cultura e política, levou um público maior às exposições. Algumas exposições, como a do próprio Manoel Martins, tiveram mais caráter político que artístico. Essa exposição tinha sido patrocinada pela Associação de Escritores, representada na Bahia por Jorge Amado que, na época, pertencia ao Partido Comunista e que lutava contra o fascismo. A mistura cultura-política foi bem próprio do período do Estado Novo como, aliás, tinha sido de todos os governos totalitários de então.

57 O período, imediatamente após a Segunda Grande Guerra quebrou convenções sociais e de linguagem, modificou a estrutura econômica, científica e tecnológica. Foi a fase de confronto entre o liberalismo e o socialismo. Começava-se a quebrar as atitudes ortodoxas e dogmáticas o que permitiu o aparecimento de duas forças contrárias em todas as áreas da atividade humana. Nas artes baianas se opunham o antigo, ou classicismo realista do neoclassicismo, e o novo que aparecia sob a designação genérica de moderno. Esse binômio, como se viu, já estava presente na ideologia que havia movido os Salões da ALA e continuava a perdurar.

Depois da exposição de José Guimarães na Bahia, mais dez anos eram passados quando alguns artistas, formados no exterior, e alguns grupos políticos, entreabriam as portas ao modernismo. Assim, somente em agosto de 1944, se tentava mostrar, coletivamente na Bahia, obras de artistas modernos. Nesse ano Manoel Martins ${ }^{68}$, vindo à Bahia para ilustrar o livro guia da cidade do Salvador, Bahia de Todos os Santos, de Jorge Amado, organizou uma exposição na Biblioteca Pública, ainda na Praça Municipal. Jorge Amado, 
vice-presidente do Núcleo Bahiano de Escritores, presidiu a cerimônia de abertura da exposição que teve Walter da Silveira como orador e que teceu considerações sobre a arte dos expositores. Manoel Martins trazia algumas de suas obras e outras de Segall, Gomide, Quirino da Silva, Lucy, Tarsila, Rebolo, Volpi, Gobbis, Oswald Andrade Filho, Walter Levy, Augusto Rodrigues, Clóvis Graciano e Flávio de Carvalho que adicionou as de Pancetti, Portinari, Cícero Dias, Di Calvalcanti, Scliar, pertencentes à colecionadores de Salvador,- especialmente a Mário Cravo e Odorico Tavares-, e mostrou-as em público.

A maior parte dos artistas, cujas obras foram trazidas por Manoel Martins, pertencia à Família Artística Paulista, que se opunha ao grupo do Salão de Maio, também paulista. A Família preferia sincronizar-se aos movimentos internacionais, enquanto os componentes do "Salão de Maio" aceitavam as inovações, mas negavam a "dextridade técnica, que pelo malabarismo e pelo truque, se sobrepõe à emoção profunda ou à pureza mentalista da arte"69. A Família Artística Paulista, extinta em 1940, surgira do Grupo do Santa Helena e sua temática prendia-se ao popular urbano de São Paulo ${ }^{70}$.

O ambiente da exposição de Manoel Martins foi montado dentro de uma nova concepção valorizando, inclusive, as características locais. Isto levou o jornal A Tarde a criticar a pobreza do ambiente, desde o pano de juta nacional que forrava as paredes, até à falta de molduras caríssimas que geralmente se $v^{2}{ }^{71}$. Os produtos nacionais e característicos de cada região vinham sendo valorizados pela intelectualidade tida como de linha de frente da modernidade. Lina Bo Bardi, que realizou o projeto museográfico do antigo Museu de Arte de São Paulo, na Rua 7 de Abril, e depois do MAMB na Bahia, escreveu: "o critério que informou a arquitetura interna do Museu restringiu-se às soluções de 'flexibilidade', à possibilidade de transformação do ambiente, unida à estrita economia que é própria do nosso tempo. Abandonaram-se os requintes evocativos e os contornos, e as obras de arte antiga não se acham expostas sobre veludo, como o aconselham ainda hoje muitos especialistas em museologia, ou sobre tecidos de época, mas colocadas corajosamente sobre fundo neutro"72. E afirmava mais adiante: "também as molduras foram eliminadas e substituídas por um filete neutro"73.

61 Houve reação por parte do público e, especialmente, por parte da imprensa. Os jornais O Imparcial e o Diário da Bahia promoveram, com o objetivo de ridicularizar os trabalhos expostos, uma mostra de rabiscos feitos a esmo, trabalhos com materiais insólitos, executados pelos próprios redatores e funcionários, colocados no hall do Palace Hotel, na Rua Chile. As obras foram denominadas Hipocondria, Tuberculose, A meia-noite, A vaca dentro de um guarda-chuva, etc. Jorge Amado, testemunha da época, disse que o jovem romancista subversivo, Wilson Lins, e o poeta Lafayette Spinola foram dos mais virulentos no ataque à exposição de arte moderna ${ }^{74}$. A reação não era só local e os movimentos anti-arte moderna foram constantes em todo o Brasil ${ }^{75}$.

Apesar dessa reação, o meio intelectual já se mostrava outro. 0 número de instituições, ligadas à educação e à arte, tinha crescido e, mesmo com a oposição dos estudantes, o reitor Edgard Santos (1946-1960) deu um dos passos mais importantes do período, unindo as escolas isoladas, já existentes ${ }^{76}$, e criando a Universidade da Bahia, trazendo nomes importantes para seu corpo docente. Em 1946 a Universidade da Bahia federalizou-se.

63 Nas suas Notas Sobre as Artes Plásticas na Bahia, Motta e Silva, ainda em 1948, dizia que "o movimento plástico não acompanhou o mesmo ritmo da evolução da literatura. Não possuímos, ainda, equivalentes plásticos dos romances de Jorge Amado, Clóvis Amorim, João Cordeiro, Akina 
Paim, e dos poemas de Sosigenes Costa, Aydano do Couto Ferraz, Santos Moraes e de Enock Santiago Filho. A revolução que aconteceu em nossa literatura não chegou a atingir as artes da pintura, da escultura e da arquitetura" "77. Reclamando a ausência de um representante das artes plásticas na Bahia, dizia que "muito ao contrário ainda subsiste entre nós o espírito reacionário e acadêmico se antepondo ao livre exercício da manifestação artística". ${ }^{78}$

No período, os pintores acadêmicos pintavam, ainda, tetos de igrejas e copiavam o que Motta e Silva chamava de decadência barroca, sob a influência dos artistas consagrados, como Vitor Meirelles e Pedro Américo, que faziam pintura de história e costumes. E criticava os jovens artistas, que tinham recebido os prêmios de viagem, de ter ido estudar em academias decadentes e, ao voltar, fazer pinturas que resultavam da produção de seus mestres e que nada tinham com a realidade nacional, porém, concluía: o que vale é que a renovação já começou. Dentre os baianos abrangidos pela crítica estavam Manoel Paraguassu, Raul Deveza, Rubens Sacramento, Robespierre de Farias e mesmo Presciliano Silva ${ }^{79}$.

65 Embora Motta e Silva apontasse um certo esmorecimento no ânimo das primeiras iniciativas inovadoras, em 1948, os próprios organismos do governo incentivavam eventos. O Diretor do Museu do Estado, Valladares, promovia, na Biblioteca Pública, conferências e exposições de pintura moderna com obras de alguns estrangeiros e brasileiros. Sob o patrocínio da Secretaria de Educação e Saúde, o crítico Mário Barata fizera diversas palestras sobre temas como: Elementos de arte moderna, Do impressionismo ao fovismo, Do cubismo aos nossos dias, Cultura como fenômeno nacional e arte, etc. Esses fatos tiveram o mérito de servir para colocar a maior parte dos artistas baianos em contato com o modernismo.

O movimento modernista baiano se firmou após o período de marasmo artístico que predominou durante a II Guerra Mundial ${ }^{80}$. A fixação das idéias modernistas na Bahia iniciava-se, portanto, na década de 1940, como acontecera nos outros Estados ${ }^{81}$, com exceção de Rio e São Paulo, especialmente no que se relacionava às artes plásticas. Em geral, surgiram em torno de um ou dois artistas que acabavam de chegar da Europa ou dos Estados Unidos.

67 Como notou Nelson Sampaio, até a Segunda Grande Guerra, na Bahia os tipos intelectuais mais festejados eram os poetas e oradores. Apenas com o aparecimento de cursos universitários diversificados, que tirariam do bacharel em Direito, do Doutor em Medicina ou do Engenheiro o prestígio social, é que a cultura passou a ter prestígio fora da área da literatura. Diria se "quisessemos resumir as tendências da nossa 'intelligentsia, apontaríamos as seguintes linhas evolutivas: o declínio da cultura verbal; a diversificação cultural; a preocupação da funcionalidade da cultura; o 'desindividualismo' cultural; 'o fim dos notáveis'; e a valorização da cultura artística. Trata-se de tendências universais, aqui chegadas com certo atraso" $"$.

68 Passada a Guerra, em 1949, foi instalado o Primeiro Salão Bahiano de Belas Artes ${ }^{83}$, que praticamente substituiu os Salões da ALA, graças aos esforços de José Valladares e Anísio Teixeira, no Governo de Otávio Mangabeira ${ }^{84}$. Os Salões foram em número de seis e se prolongaram de 1949 até 1956.

69 O Salão Bahiano de Belas Artes foi criado em comemoração ao IV Centenário da Fundação da Cidade do Salvador. Foi instalado com Comissão Organizadora oficial e os prêmios aprovados, por decreto, para expor, anualmente durante a primavera, trabalhos divididos em cinco seções: pintura, escultura, desenho, gravura e 
arquitetura $^{85}$ em duas divisões: Geral e Moderna. Embora parcialmente, institucionalizava-se, finalmente, a arte moderna.

\section{BIBLIOGRAFIA}

ALCOFORADO, Fernando. Vetores de expansão no século XX. A Tarde. Bahia, 1 out.1992, p. 3.

ALMEIDA, Paulo Mendes de. De Anita ao museu. Conselho Estadual de Cultura, São Paulo, 1961.

ALVES, Ivia. A imprensa e o modernismo. A Tarde Cultural, Bahia, 10 out.1992, p. 4-5.

ALVES, Ivia. Arco \& Flexa, contribuição para o estudo do modernismo. Fundação Cultural do Estado da Bahia, Salvador, 1978.

ALVES, Marieta. Mestres ourives do ouro e prata da Bahia. Museu do Estado da Bahia, Salvador, 1962.

AMARAL, Aracy et al.. Modernidade arte brasileira do século XX. Câmara do Comércio e Indústria Franco-Brasileira/MEC, São Paulo, 1988.

ANDRADE, Mário de. O movimento modernista. In: BERRIEL, Carlos Eduardo (org.). Mário de Andrade/ hoje. Ensaio, 1990, São Paulo,. p. 15-39.

ANDRADE, Mário de.. Aspectos das artes plásticas no Brasil. Martins, São Paulo, 1975.

ANDRADE, Rodrigo Melo Franco de. Do pau-brasil à antropofagia e às utopias. Civilização Brasileira, Rio de Janeiro, 1972.

ANDRADE, Rodrigo Melo Franco de. (dir.). As artes plásticas no Brasil. Edições de Ouro, Rio de Janeiro, 1968.

BARDI, Lina Bo. Pequenos cacos, fiapos e restos de civilização. A Tarde Cultural, Bahia, 23 out.1992. p. 8.

BARDI, Pietro. 0 modernismo no Brasil. Banco Francês e Italiano para a América do Sul, São Paulo, 1978.

BRASIL, Ivaldo. A prova dos nove(nta). Ô Catarina! Florianópolis, n. 5, p. 3-6, 1993.

BRITO, Mário da Silva. História do modernismo brasileiro: antecedentes da Semana de Arte Moderna, 3ed., Civilização Brasileira, Rio de Janeiro, 1971.

BULHÕES, Maria Amélia; KERN, Maria Lúcia BASTOS (org.). A Semana de 22 e a emergência na modernidade no Brasil. Secretaria Municipal da Cultura, Porto Alegre, 1992.

CALAZANS, José. Cachaça, moça branca. Secretaria de Educação e Cultura, Bahia, 1951.

CALDERON, Valentim. José Guimarães. Museu de Arte Sacra da UFBa, Salvador, 1975.

CALMON, Pedro. História da fundação da Bahia. Vitória, Bahia, 1949.

CAMPOS, João da Silva. Procissões tradicionais da Bahia. Imprensa Oficial, Bahia, 1941.

CAMPOS, João da Silva. Tempo antigo. Imprensa Oficial, Bahia, s.d.

CASTRO, Renato Berbert de. A sucessão de Carlos Chiacchio na Academia de Letras da Bahia. In:

REVISTA DA ACADEMIA DE LETRAS DA BAHIA, Salvador, n. 42, p. 83-98, mai. 1996. 
CELESTINO, Antônio. Da moderna pintura baiana. In: 150 anos de pintura na Bahia. Catálogo. Comissão do Sesquicentenário da Independência da Bahia MAMB, Salvador, 1973.

CELESTINO, Antônio. Do advento da arte moderna na Bahia e de sua memória. A Tarde, Salvador, 26 fev. 1982, cad. 2, p. 3.

CHIACCHIO, Carlos. Modernistas e ultramodernistas. Progresso, Salvador, 1951.

CHIACCHIO, Carlos. Os Salões de Ala. A Tarde, Salvador, 8 out.1941.

CHIACCHIO, Carlos. V Salão de Ala, Pasquale de Chirico. A Tarde, Salvador, 1 out.1941.

CHIACCHIO, Carlos. Biocrítica, Jornal de Ala, Bahia, 1939.

CHIACCHIO, Carlos. Justificação (discurso de lançamento de ALA, Escola de Belas Artes da Bahia, 1936) Ala das Letras e das Artes, Bahia, 1938.

COÊLHO, Ceres Pisani Santos. Artes plásticas; movimento moderno na Bahia. EBAUFBa, Salvador, 1973. (mimeo)

COSTA, Selma Fraga. As artes plásticas e o modernismo na Bahia. A Tarde, Bahia, 12 out.1992, p. 3.

DIÁRIO da Bahia, Bahia, 15 jan.1874, p. 4.

DIÁRIO DE NOTICIAS, Bahia, 10 jan. 1877, p. 1; 22 jun. 1877, p. 2.

DIAS, Fernando Correia. Gênese e expressão grupal do modernismo em Minas. In: ÁVILA, Affonso (coord.). O modernismo. Perspectiva, São Paulo, 1975. p. 165-177.

DO. DIÁRIO OFICIAL DA BAHIA, Edição Especial do Centenário, 1823-1923. Imprensa Oficial, Bahia, 1923, p. 457, 497.

EDELWEISS, Frederico. Tupis e guaranis. Imprensa Oficial, Bahia, 1947.

EXPOSIÇÃO DE MANOEL MARTINS, Diário de Notícias, Bahia, 17 ago 1944, p. 2 , 3.

FABRIS, Annateresa (org.). Modernidade e modernismo no Brasil. Mercado das Letras, Campinas/SP, 1994.

FALLA com que no dia 3 de abril de 1881 abriu a $2^{\mathrm{a}}$ sessão da $23^{\mathrm{a}}$ Legislatura da Assembléa Legislativa Provincial da Bahia o Illm. e Exm. Sr. Conselheiro João Lustosa da Cunha Paranaguá, Presidente da Província da Bahia. Diário da Bahia, Bahia, 1881.

FLEXOR, Maria Helena Ochi. J.J. Seabra e a Reforma urbana de Salvador. In: Cidades brasileiras; políticas urbanas e dimensão cultural. Instituto de Estudos Brasileiros, São Paulo, 1998. p. 108-119. (Projeto de cooperação CAPES/COFECUB).

FLEXOR, Maria Helena Ochi. Academia Imperial de Belas Artes: 'inspiração' da Academia de Belas Artes da Bahia. In: ANAIS DO SEMINÁRIO EBA 180. UFRJ, Rio de Janeiro, 1997. p. 281-306.

FLEXOR, Maria Helena Ochi. O regionalismo na arte moderna brasileira: Bahia. Comunicação apresentada no XX Colóquio Brasileiro de História da Arte, do Comitê Brasileiro de História da Arte, São Paulo, set. 1997.

FRANÇA, Acácio. A pintura na Bahia. Secretaria de Educação e Saúde/Imprensa Oficial, Bahia, 1944. GOMES, João Carlos Teixeira. Camões contestador e outros ensaios. Fundação Cultural do Estado da Bahia, Salvador, 1979.

GUELFI, Maria Lúcia Fernandes. Novíssima; contribuição para o estudo do modernismo. Instituto de Estudos Brasileiros, São Paulo, 1987. 
HERSKOVITS, Melville. Pesquisas etnográficas na Bahia. Secretaria de Educação e Saúde/Imprensa Oficial, Bahia, 1943.

KERN, Maria Lúcia Bastos. A pintura modernista no Rio Grande do Sul. In: BULHÕES, Maria Amélia; KERN, Maria Lúcia Bastos (org.). A Semana de 22 e a emergência na modernidade no Brasil. Secretaria Municipal da Cultura, Porto Alegre, 1992. p. 46-54.

LEITE, José Roberto Teixeira. Pintura moderna brasileira. Record, São Paulo, 1978.

LEITE, Lígia C. Moraes. Regionalismo e modernismo. Ática, São Paulo, 1978.

LIVRO DE ACTAS das Sessões de Congregação da Escola de Belas Artes da Bahia, 1896, n. 4, 96 fls., ms.

LUDWIG, Selma Costa. Mudanças na vida cultural de Salvador - 1950-1970. Universidade Federal da Bahia, Salvador, 1982. (mimeo)

LUDWIG, Selma Costa. A Escola de Belas Artes cem anos depois. Centro de Estudos Baianos, Salvador, 1977.

MAGALHÃES, Emídio. Considerações sobre pintura: história, técnica, princípios. Escola Técnica. Salvador, s. d.

MARTINS, Wilson. O modernismo, 1916-1945, 3ed. Cultrix, São Paulo, 1964.

MASCARENHAS, Dulce. Carlos Chiacchio: homens \& obras; itinerário de dezoito anos de rodapés semanais em A Tarde. Fundação Cultural do Estado da Bahia, Salvador, 1979.

MORAES, Eduardo Jardim de. Mário de Andrade: retrato do Brasil. In: BERRIEL, Carlos Eduardo (org.). Mário de Andrade/hoje. Ensaio, São Paulo, 1990. p. 67-102.

MUSEU DE ARTE MODERNA DA BAHIA. O modernismo na Bahia. Catálogo. Sala Especial do 1ํㅗãão MAM-BA de Artes Plásticas, Teatro Castro Alves, Salvador, 1994.

OLIVEIRA, Zélia Maria Póvoas de. Desenho-ensino-comunidade. Estuário, Salvador, 1970.

PARAISO, Juarez. 1912-1982: 80 anos de artes visuais. A Tarde, Bahia, 12 out. 1992. p. 4-5.

PARAISO, Juarez. Trinta anos depois. Tribuna da Bahia, Salvador, 21 jan.1973, p. 2.

PEDROSA, Mário. A Bienal de cá para lá. In: GULLAR, Ferreira (coord.). Arte brasileira hoje. Paz e Terra, Rio de Janeiro ,1973. p. 3-64.

PEIXOTO, Afrânio. Breviário da Bahia, 2ed. Agir, Rio de Janeiro, 1946.

PERES, Fernando da Rocha. Mário de Andrade; o viajante guardador. Revista da Academia de Letras da Bahia, Salvador, n. 42, p. 69-77, mai. 1996.

PERES, Fernando da Rocha. Modernismo, legado em dois percursos. São Paulo e Bahia. A Tarde Cultural, Salvador, 8 out. 1992, p. 2.

PONTUAL, Roberto. Jenner: a arte moderna na Bahia. Civilização Brasileira, Rio de Janeiro, 1974.

PONTUAL, Roberto. Arte/Bahia/Hoje, 50 anos depois. Collectio, São Paulo ,1973.

PONTUAL, Roberto. Dicionário das artes plásticas no Brasil. Civilização Brasileira, Rio de Janeiro, 1969.

PROJETO ARTES PLÁSTICAS NA BAHIA. MODERNISMO. Catálogo. Secretaria de Cultura do Estado de São Paulo/DEMAP/MAMB, Salvador s.d.

QUERINO, Manuel R.. Artistas baianos, indicações biográficas, 2ed. A Bahia, Bahia, 1911. 
REIS, Antônio Alexandre Borges dos (Org.). Almanak do Estado da Bahia, 1904-1905; Litho-Typ. e Encadernação de Reis e C., Bahia, 1904.

REIS, Antônio Alexandre Borges dos (Org.). Almanak administrativo, indicador, noticioso, commercial e literario do Estado da Bahia para 1899. Wilcke, Picard, Bahia, 1899.

RIBEIRO, Marília Andrés. Modernismo e vanguardas: os olhares artísticos de Minas. Revista Locus, Juiz de Fora/MG, v. 2, n. 1, p. 87-97, 1996.

RUIDOSA POESIA DOS CAFÉS (A). A Tarde Cultural, Salvador, 3 abr.1993, p. 2-4.

SALLES, David. Primeiras manifestações da ficção na Bahia. Universidade Federal da Bahia, Salvador, 1973.

SAMPAIO, Nelson de Souza. Salvador em 60 anos. Revista de Cultura da Bahia, Salvador, n. 7, p. 15-20, jan/dez. 1972.

SAMPAIO, Nelson de Souza. Meio século de política baiana. A Tarde, Salvador, 15 out. 1962.

SCALDAFERRI, Sante. Arte moderna na Bahia. In: PONTUAL, Roberto. Jenner: a arte moderna na Bahia. Civilização Brasileira, Rio de Janeiro, 1974. p. 69-74.

SCALDAFERRI, Sante et al. Os primórdios da arte moderna na Bahia: depoimentos, textos e considerações em torno de José Tertuliano Guimarães e outros artistas. Fundação Casa de Jorge Amado/ FCEBA / Museu de Arte da Bahia, Salvador, 1997.

SILVA, Motta e. As artes plásticas na Bahia. Caderno da Bahia, Salvador, n. 2, p. 2-9, out.1948.

SIMÕES, Isa Maria Drummond. O grupo modernista baiano de Arco \& Flexa. S.c.p., Bahia, 1975.

SMITH, Robert C. Arquitetura colonial baiana: alguns aspectos de sua história. Secretaria de Educação e Saúde, Bahia, 1951.

SPALA EDITORA. Aspectos da pintura brasileira. Spala, São Paulo, 1979.

TARDE (A). Depoimento de Eugênio Gomes, “A Tarde”, Bahia, 1932.

TELES, Gilberto Mendonça. Vanguarda européia e modernismo brasileiro. Vozes, Rio de Janeiro, 1972. TRINDADE, Hélgio. O integralismo, o fascismo brasileiro na década de 30, 2ed. DIFEL, São Paulo, 1979.

VALLADARES, José do Prado. Artes maiores e menores, seleção de crônicas de arte, 1951-1956. Progresso, Bahia, 1957.

VALLADARES, José do Prado. Arte moderna na Bahia. Diário de Notícias, Bahia, 17 jun. 1951, p. 2.

VALLADARES, José do Prado. Dominicais: seleção de crônicas de arte de 1948-1950. Artes Gráficas, Bahia, 1951.

VALLADARES, José do Prado. A Galeria Abbott; primeira pinacoteca da Bahia. Secretaria de Educação, Bahia, 1951.

VALLADARES, José do Prado. Museus para o povo. Imprensa Oficial, Bahia, 1946.

VALLADARES, José do Prado. As belas artes na Bahia. In: Cidade do Salvador, Habitat, São Paulo, s. d.,

VIANNA JÚNIOR, Antônio Gonçalves. Casos e coisas da Bahia. Beneditina, Bahia, 1950.

WAGLEY, Charles. Uma pesquisa sobre a vida social do Estado. Secretaria de Educação e Cultura, Bahia, 1950.

ZANINI, Walter. O Grupo Santa Helena. Museu de Arte Moderna de São Paulo, São Paulo, 1996. 
ZANINI, Walter. A arte no Brasil nas décadas de 1930-40: o Grupo Santa Helena. Nobel/EDUSP, São

Paulo, 1991 .

ZANINI, Walter. (Org.). História geral da arte no Brasil. Instituto Walther Moreira Salles, São Paulo, 1983. v.2.

ZILBERMAN, Regina. Modernismo periférico no Rio Grande do Sul. In: BULHÕES, Maria Amélia; KERN, Maria Lúcia Bastos (org.). A Semana de 22 e a emergência na modernidade no Brasil. Secretaria Municipal da Cultura, Porto Alegre, 1992. p. 39-45.

ZILIO, Carlos. O nacional e o popular na cultura brasileira. Brasiliense, São Paulo, 1982.

\section{NOTAS}

1. Embora os autores deem a origem das imagens feitas em armação de madeira e apenas as partes nobres, - pés, mãos, rosto -, esculpidas na roca de fiar, na realidade vem de roca, - rocha -, em espanhol. As rochas faziam parte do cenário das cenas da Paixão de Cristo, quando as imagens de roca saiam procissão.

2. Excetuando-se o teto da Igreja do Bomfim.

3. QUERINO, Manuel. Artistas baianos, p. 69.

4. OLIVEIRA, Zélia Maria Póvoas de. Desenho-ensino-comunidade, p. 12.

5. OlLIVEIRA, Zélia Maria Póvoas de. Op. cit., p. 12.

6. Autor da pintura do teto da Igreja do Bomfim.

7. QUERINO, Manuel. Op. cit., p. 104.

8. QUERINO, Manuel. Op. cit., p. 105-106.

9. 2 de Julho de 1823 data da Independência da Bahia.

10. QUERINO, Manuel. Op. cit., p. 107-108.

11. QUERINO, Manuel. Op. cit., p. 110, 112.

12. Com a criação do Liceu Provincial, a cadeira de desenho foi desmembrada, ficando na dependência direta do Diretor Geral de Ensino, estabelecida pelo \# 31 da Lei n.105, de 23 de junho de 1868.

13. Coleção feita pelo médico escocês Jonathas Abbott que viveu, e morreu, na Bahia.

14. FALLA com que no dia 3 de abril de 1881 abriu a $3^{a}$ sessão da $23^{a}$ Legislatura da Assembléa Legislativa Provincial da Bahia, o Illm. E exmo. Sr. Conselheiro João Lustosa da Cunha Paranaguá, p. 30.

15. DIÁRIO DE NOTÍCIAS, 10 jan. 1877, p. 2.

16. DO. DIÁRIO OFICIAL DA BAHIA, Edição Especial do Centenário, 1823-1923, p.497; FLEXOR, Maria Helena Ochi. Academia Imperial de Belas Artes, p. 294.

17. Ainda em 1899 e 1904, alguns artistas que trabalhavam à maneira do século XVIII e anunciavam seus nomes nos Almanaques da Bahia, como escultores, entalhadores e encarnadores, mas, já apareciam retratistas-pintores, como Antônio Olavo Batista, Manoel Lopes Rodrigues, Oséas dos Santos, Vieira de Campos, conhecidamente de estilo neoclássico. REIS, Antônio Alexandre Borges dos (org.). Almanak administrativo, indicador, noticioso,.... 1899, p. 530-532,556, 560; REIS, Antônio Alexandre Borges dos (org.) Almanak do Estado da Bahia, p. 502, 503, 535.

18. SAMPAIO, Nelson de Souza. Meio século de política baiana, p.15.

19. FLEXOR, Maria Helena Ochi. J. J. Seabra e a reforma urbana de Salvador, p. 108-119.

20. Mário Cravo Júnior, Carybé, Jenner Augusto, Carlos Bastos, Genaro de Carvalho, Lygia Sampaio, entre outros. 
21. Enquadra-se nessas definições a produção artística que marcou uma mudança na sensibilidade, no discurso e na prática cultural.

22. VALLADARES, José do Prado. Arte moderna na Bahia, p. 2.

23. COÊLHO, Ceres Pisani Santos. Artes plásticas: movimento moderno na Bahia, 223p.

24. SCALDAFERRI, Sante. Arte moderna na Bahia, p. 69-74; SCALDAFERRI, Sante et al. Os primórdios da arte moderna na Bahia: depoimentos, textos... 182p.

25. PONTUAL, Roberto. Jenner: a arte moderna na Bahia, 183p.

26. LUDWIG, Selma Costa. Mudanças na vida cultural de Salvador, $169 \mathrm{p}$.

27. PARAÍSO, Juarez. 1912-1982: 80 anos de artes visuais, p. 4-5.

28. Vide, por exemplo, PONTUAL, Roberto. Dicionário das artes plásticas no Brasil, 559p.

29. De 1920 a 1940 a população passou apenas de 283.422 para 290.443 habitantes. SAMPAIO, Nelson de Souza, Salvador em 60 anos, p. 17.

30. Médico, político e vice-presidente de Prudente de Morais.

31. FLEXOR, Maria Helena Ochi. J. J. Seabra..., p. 113.

32. Exemplos marcantes foram o Palácio do Governo, o edifício da Associação dos Empregados no Comércio, o Kursaal Baiano.

33. Uma das principais academias, freqüentada por todos os baianos que receberam a pensão de estudos em Paris, foi a Academia Julian.

34. OLIVEIRA, Zélia Maria Póvoas de. Op. cit. p. 27.

35. OLIVEIRA, Zélia Maria Póvoas de. Op. cit. p. 27.

36. LIVRO DE ATAS da Congregação da Escola de Belas Artes da Bahia, 10 ago.1892, fl. 135; 24 nov. 1893, fl. 144.

37. LIVRO DE ATAS da Congregação da Escola de Belas Artes da Bahia, 14 fev. 1894, fl. 144, 145; FLEXOR, Maria Helena Ochi. Academia Imperial, p. 298. Um anúncio de jornal, de 1874, mostrava, inclusive, o uso corrente da fotografia como modelo: 'Photographia Imperial", Rua Direita de Palácio, sobrado n. 7", dizia, Photographie Bombé, imitando esmalte, colorido ou não, e retrato a óleo por 'habilissimo artista', podendo tirar a foto para remeter ao pintor. DIÁRIO da Bahia, 15 jan.1874, p. 4.

38. RUIDOSA POESIA DOS CAFÉS (A), p. 3.

39. Surgida em julho de 1931 teve 9 números, publicados até 1932.

40. GOMES, João Carlos Teixeira. Camões contestador e outros ensaios, p. 189. Entre seus colaboradores estavam: João Cordeiro, Edison Carneiro, Dias da Costa, E. Assemany, Machado Lopes, Dias Gomes, Sosígenes Costa. O mesmo periódico lançou as revistas "Flama", "Luva", "Seiva", "Hoje", "Revista da Bahia".

41. Chiacchio pertenceu a Academia de Letras da Bahia, tendo sido o fundador da cadeira n. 5 , embora nascido em Januária, Minas Gerais. Os estatutos da Academia, para admitir intelectuais que não haviam nascido na Bahia, criou, no \# 1 do Art. $2^{\circ}$ a possibilidade de se admitir três membros efetivos nascidos fora da Bahia, mas residentes em Salvador. CASTRO, Renato Berbert de. A sucessão de Carlos Chiacchio na Academia de Letras da Bahia, p. 84.

42. CHIACCHIO, Carlos. Biocrítica, p. 2; ALVES, Ivia. Arco \& Flexa, contribuição para o estudo do modernismo, p. 29.

43. Em Minas Gerais, segundo Correia Dias, havia um interesse pela Minas Colonial, movido por duas motivações: a valorização cultural da região e a retomada da continuidade da vida intelectual mineira. E frisava que, quanto a este último pretendiam romper com os padrões estéticos da geração imediatamente anterior (que se aprofundara no mais estéril academismo e era tida como passadista), mas não com todo o passado literário mineiro. Pelo contrário, faziam questão de afirmar a ascendência sobre eles, remotamente, dos poetas da Arcádia e, proximamente, de Alphonsus de Guimarães. DIAS, Fernando Correia. Gênese e expressão grupal do modernismo em Minas, p. 10. Isto se opõe á afirmação de Ludwig, ao analisar do grupo Arco e Flexa, dizendo que limitou-se a refletir o tradicionalismo conservador da Bahia, retardando a evolução de toda uma geração de novos. LUDWIG, Selma Costa. Ob. cit. p. 22, 33. o período era muito mais complexo. 
44. ALVES, Ivia. Ob. cit. p. 13, 24, 26.

45. O mesmo processo acusou Guilhermino César para o Rio Grande do Sul. ZILBERMAN, Regina. Modernismo periférico no Rio Grande do Sul, p. 39.

46. MORAES, Eduardo Jardim de. Mário de Andrade: retrato do Brasil, p. 70.

47. MASCARENHAS, Dulce. Carlos Chiacchio: homens \& obras; itinerário de dezoito anos de rodapés semanais em A Tarde, p. 20.

48. Robatto realizou vários documentários para o governo.

49. Já tendia ao regionalismo. Chiacchio dizia que Ala tinha o propósito de estudar a cultura baiana em todas as suas manifestações vitais, embora não abarcasse, com muita ênfase, a cultura negra predominante na Bahia.

50. LUDWIG, Selma Costa. Ob. cit., p. 133-135

51. LUDWIG, Selma Costa. Ob. cit., p. 133-135.

52. CHIACCHIO, Carlos, Os salóes de Ala, p. 3.

53. Com o quadro "Rue à Douarnenez".

54. Localizada na 31, rue de Dragon, Paris VIe, onde se ensinava pintura, escultura e arquitetura.

55. PROJETO ARTES PLASTICAS NA BAHIA. Modernismo. Catálogo, s.p.

56. PERES, Fernando da Rocha. Modernismo, legado em dois percursos, p. 2.

57. Depoimento de Eugênio Gomes. In: VALLADARES, José do Prado. Dominicais: seleção de crônicas de arte de 1948-1950. Bahia: Artes Gráficas, 1951.

58. VALLADARES, José do Prado. Artes maiores e menores, seleção de crônicas de arte, p. 76.

59. SCALDAFERRI, Sante. Op. cit., p. 69.

60. PEIXOTO, Afrânio. Breviário da Bahia, p. 287.

61. MAGALHÃES, Emídio. Considerações sobre pintura: técnica, princípios., p. 65-66.

62. Criado pela Lei n. 1.255, de 23 de julho de 1918, apareceu como secção anexa ao Arquivo Público do Estado. Em 20 de janeiro de 1931, pelo Decreto n. 7.205, criou-se a Pinacoteca do Estado que passou a dependência do Museu do Estado.

63. Por convênio, uma parte funcionou, a partir de 1968, no Convento do Carmo e, depois, mudou-se, inteiramente, em 1982, para o palácio da Vitória.

64. Foram editados: CAMPOS, João da Silva. Procissões tradicionais da Bahia, 192 p.; CAMPOS, João da Silva. Tempo antigo, 83 p.; HERSKOVITS, Melville. Pesquisas etnográficas na Bahia, 20p.; FRANÇA, Acácio. A pintura na Bahia, 74p.; VALLADARES, José do Prado. Museus para o povo, 105p.; EDELWEISS, Frederico. Tupis e guaranis, 220p; CARNEIRO, Edison. Candomblés da Bahia,140p.; CALMON, Pedro. História da fundação da Bahia, 257p.; VIANNA JÚNIOR, Antônio Gonçalves. Casos e coisas da Bahia.105p.; WAGLEY, Charles. Uma pesquisa sobre a vida social do Estado; SMITH, Robert C. Arquitetura colonial baiana: alguns aspectos de sua história. 73p.; VALLADARES, José do Prado. A Galeria Abbott; primeira pinacoteca da Bahia. 86p.; CALAZANS, José. Cachaça, moça branca, 112p.; ALVES, Marieta. Mestres ourives do ouro e prata da Bahia, $83 \mathrm{p}$.

65. VALLADARES, José do Prado. Artes maiores e menores..., p. 83-85.

66. ALCOFORADO, Fernando. Vetores de expansão no século XX, p. 3.

67. O MASP - Museu de Arte de São Paulo - foi criado em 1947, o MAM - Museu de Arte Moderna de São Paulo, em 1948 e o MAM do Rio de Janeiro em 1949. PEDROSA, Mário. A Bienal de cá para lá, p. 33.

68. Segundo Jorge Amado, Manoel Martins viera por pouco tempo, mas, enamorado pela cidade, ficou durante meses. (MUSEU DE ARTE MODERNA DA BAHIA. O modernismo na Bahia, s.p.

69. Sem o intelectualismo dos integrantes da "Semana de Arte Moderna, o "Grupo Santa Helena" formou-se, a partir de 1935, com a instalação do ateliê do pintor Francisco Rebollo, no Edifício Santa Helena, na Praça da Sé, sala 213. SPALA EDITORA.Aspectos da pintura brasileira, p. XLIV.

70. PONTUAL, Roberto. Arte/Bahia/Hoje, p. 30. Foi no bairro proletário do Cambuci que surgiu o Grupo Santa Helena que, junto com o Braz, Moóca, Lapa, se opunha ao ambiente aristocratoburguesa da Semana de 22. 


\section{EXPOSIÇÃO DE MANOEL MARTINS, p.2, 3.}

72. Os produtos nacionais e característicos de cada região vinham sendo valorizados pela intelectualidade tida como de linha de frente da modernidade.

73. BARDI, Lina Bo. Pequenos cacos, fiapos e restos de civilização, p. 8.

74. MUSEU DE ARTE MODERNA DA BAHIA. Ob. cit., s.p.

75. No Rio Grande do Sul chegou-se a promover o $1^{\circ}$ Salão Moderno de Artes Plásticas, em 1942, para ridicularizar a arte moderna, bem com se fez publicar o Manifesto Anti-Modernista. KERN, Maria Lúcia Bastos. A pintura modernista no Rio Grande do Sul, p. 49. Em Belo Horizonte ocorreram manifestações de estudantes esquerdistas, na praça central da cidade, parodiando a exposição modernista, com uma mostra de rabiscos nos tapumes do Banco da Lavoura. Numa exposição, um visitante anônimo revoltou-se, rasgando uma das telas de Portinari que era tido como pintor oficial da ditadura. Reagiam contra a Semana de Arte Moderna, de 1944, promovida pela prefeitura no governo de Juscelino Kubitschek RIBEIRO, Marília Andrés. Modernismo e vanguardas: os olhares artísticos de Minas, p.90-91. Na opinião de alguns, os modernistas manifestaram interesse pela política, suas opções iam tanto para a esquerda, quanto para a direita, apresentando todos, o nacionalismo como objetivo comum. TRINDADE, Hélgio. 0 integralismo, o fascismo brasileiro na década de 30, p. 29.

76. Escola de Medicina, criada a partir da chegada de D. João VI a Bahia, Escola de Belas Artes, fundada em 1877, Escola Politécnica, Escola de Direito, ambas dos finais do século XIX, Faculdade de Filosofia, criada em 1943.

77. SILVA, Motta e. As artes plásticas na Bahia, p. 2.

78. SILVA, Motta e. Op. cit., p. 3, 9.

79. SILVA, Motta e. Op. cit., p. 3, 9.

80. BRASIL, Ivaldo. A prova dos nove(nta), p. 4.

81. ZANINI, Walter (org.). História geral da arte no Brasil, p. 726-727.

82. SAMPAIO, Nelson. Salvador em 60 anos, p. 19.

83. No período, criou-se o Salão Universitário Bahiano de Belas Artes, do qual vários desses artistas participaram, iniciativa extra-curricular dos alunos do Curso de Arquitetura da Escola de Belas Artes que, de forma indireta, participava do movimento renovador .COÊLHO, Ceres Pisani Santos. Op cit., p. 18.

84. Instituído pelo Decreto n. 14.314, de 8 de março de 1949.

85. 0 Curso de Arquitetura ainda funcionava na Escola de Belas Artes.

\section{RESUMOS}

Estudo dos primeiros passos que marcaram a passagem do barroco, que por mais de um século atingiu a arte e a visão de mundo dos baianos, para o neoclassicismo e a lenta passagem para o modernismo, entre 1928 e 1949. Como a Semana de 1922, a arte moderna na Bahia teve reflexos do futurismo italiano e, da mesma forma, teve a liderança de literatos para atingir, gradativamente, os artistas plásticos até ser reconhecida oficialmente.

Étude des premier pas qui ont marqué le passage du baroque, qui, pendant plus d'un siècle a atteint l'art et la vision du monde des bahianais, vers le néoclassicisme et la lente transition vers le modernisme, entre 1928 et 1949. Semblablement à la Semana de 1922, l'art moderne de Bahia a 
été un reflet du futurisme italien et, également, a pris la tête des écrivains pour atteindre progressivement les artistes pour enfin être reconnu officiellement.

\section{ÍNDICE}

Palavras-chave: Bahia, arte baiana, neoclassicismo, modernismo, movimento de ALA, literatos, artistas modernos

\section{AUTOR}

\section{MARIA HELENA OCHI FLEXOR}

Professora emérita da Universidade Federal da Bahia; professora da Universidade Católica do Salvador, professora de história da arte, história do urbanismo e metodologia da pesquisa. 